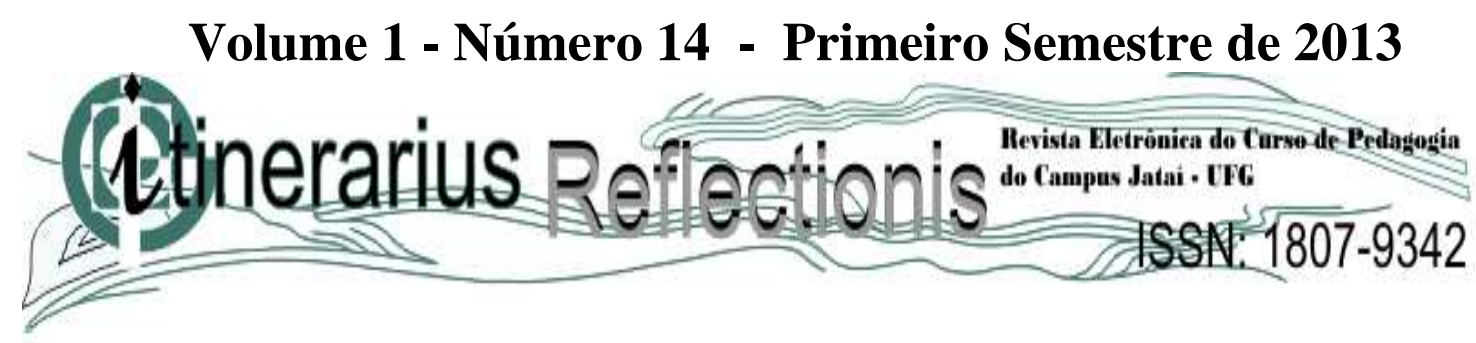

\title{
PROJETO DE HORTA ESCOLAR: ESTUDO DE CASO NO COLÉGIO DA POLICIA MILITAR DE RIO VERDE - GO
}

\author{
Marluz Martins Cabral, Bióloga, discente do Curso de Pós-Graduação Lato Sensu em Ensino \\ de Ciências e Matemática, do IFG, Campus Jataí. marluzmcrv@ hotmail.com Endereço: Rua \\ Pietro Ubalde $n^{\circ} 48$ Bairro André Luiz Rio Verde - GO \\ Marluce Silva Sousa, Mestre em Geografia, docente do Instituto Federal de Educação, Ciência \\ e Tecnologia de Goiás, Câmpus Jataí. mss_geo@hotmail.com
}

RESUMO: O objetivo deste trabalho foi analisar a proposta de horta na escola avaliando, como estudo de caso, a execução do projeto de horta escolar no Colégio da Polícia Militar de Rio Verde - GO. Inicialmente, explorou-se o tema por meio de revisão de literatura. Em seguida, foi realizada uma caracterização do Colégio Militar de Rio Verde, com observações e com levantamento de dados qualitativos, por meio de questionário e entrevista com os envolvidos. Estes dados foram analisados e confrontados com aquilo que constava no projeto de Horta Escolar. A análise permite dizer que o desenvolvimento do projeto tem pontos positivos e negativos. A horta oportuniza, tanto para os alunos como para o professor, um laboratório de buscas e aprendizagem com as informações e a prática e incentiva a valorizar o meio ambiente. Além disso, é um excelente instrumento pedagógico e conscientiza os alunos a terem hábitos alimentares saudáveis. Mas, ao mesmo tempo, falta motivação e comprometimento ou, até mesmo, incentivo aos alunos. Assim, é preciso encontrar estratégias para resgatar a participação dos alunos e buscar, em várias disciplinas, interação dos professores para executar uma verdadeira interdisciplinaridade.

Palavras-Chave: Educação Ambiental; Horta Escolar; Alimentação Saudável.

ABSTRACT:The objective of this study was to analyze the proposed garden at the school, evaluating, as a case study, the implementation of the school garden project at the College of Military Police of Rio Verde - GO. It was made an exploration of the theme through literature review. We performed a characterization of the Military College of Rio Verde, with observations and qualitative data collection through questionnaire and interview everyone involved. These data were analyzed and compared with what the project consisted of Garden School. The analysis allows saying that the development project has positives and negatives points. The garden provides an opportunity for the students and the teacher, a laboratory searches and learning with information and practice, encourages valuing the environment. Moreover, it is an excellent teaching tool and educates students to have healthy eating habits, but at the same time lack 


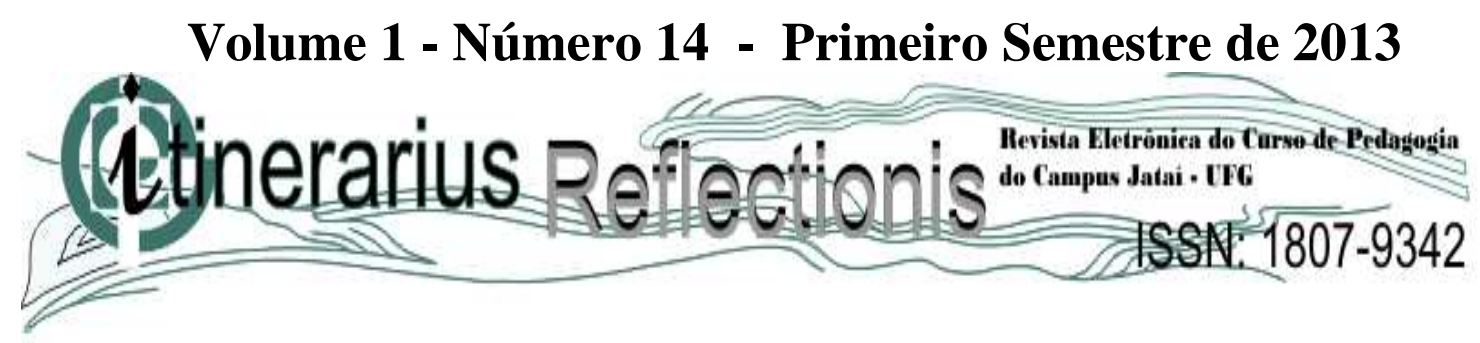

motivation and commitment or even encouragement to students. So we need to find strategies to rescue the students' participation and seek, in various disciplines, interaction of teachers to run a true interdisciplinary.

Keywords: Environmental Education; Garden School; Healthy Eating.

\section{INTRODUÇÃO}

A alimentação saudável constitui requisitos básicos para a promoção e a proteção da saúde, possibilitando a afirmação plena do potencial de crescimento e desenvolvimento humano, com qualidade de vida e cidadania.

Observa-se que, em muitas escolas públicas, os alunos são carentes e muitos deles têm como principal, senão única, a refeição oferecida na escola. Neste sentido os projetos de hortas escolares desenvolvidos nas escolas públicas podem colaborar para diminuir a fome, mas também visam a uma melhoria nos hábitos alimentares, buscando despertar o interesse ao consumo de alimentos saudáveis como: legumes, frutas e verduras.

Além de promover hábitos saudáveis pelo consumo dos produtos cultivados, a horta escolar visa desenvolver o trabalho de educação ambiental, levando a conhecimento dos alunos a importância do desenvolvimento sustentável. Alguns projetos, ainda, trabalham com plantas medicinais nas hortas escolares.

Analisando os resultados obtidos pelo IBGE (2011), percebe-se que a maioria das crianças e adolescentes, hoje, tem hábitos alimentares inadequados para o crescimento saudável. Consumindo alimentos sem muito valor nutritivo ou com exageros nas gorduras e açúcares, consequentemente, os jovens tornam-se propícios a adquirir doenças que vão da anemia à obesidade, por exemplo.

Nesse contexto, este trabalho tem como objetivo analisar a proposta de horta na escola, avaliando, como estudo de caso, a execução do projeto de horta escolar no Colégio da Polícia Militar de Rio Verde - GO, enfocando e integrando os elementos supracitados: melhoria alimentar/saúde e possibilidades de melhoria na aprendizagem de disciplinas relacionadas ao tema. Assim, será feito um confronto entre as proposições no projeto e a realidade na sua 


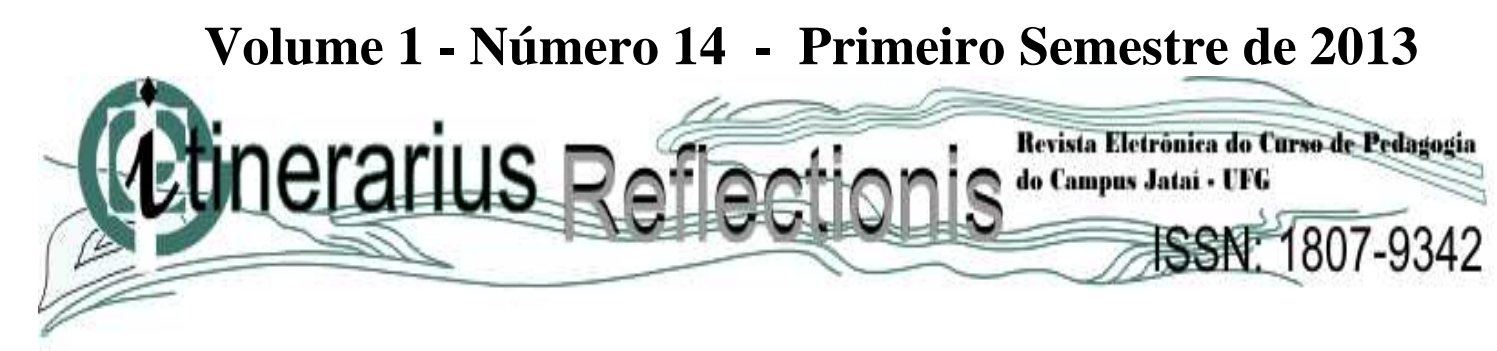

execução.

\section{REVISÃO DE LITERATURA}

\subsection{A horta escolar como estratégia pedagógica}

Segundo Segura (2001), o trabalho na horta proporciona uma convivência mais descontraída, a participação direta dos alunos e a valorização do ambiente escolar, que são significativos para estimular a participação efetiva na conservação do ambiente.

A autora afirma, ainda, que a horta apresenta-se como uma alternativa para tornar o espaço escolar mais agradável, mais familiar e resgatar valores desgastados, como a cooperação e a utilização sustentável dos recursos naturais.

Louro, Salomão e Pereira (2011) propuseram a construção de horta em creche, para trabalho com a disciplina de Ciências com crianças de 4 a 6 anos. Segundo eles, o trabalho prático e as abordagens lúdicas de conteúdos escolares junto às crianças podem contribuir para a aquisição de valores (trabalho coletivo, disciplina, compromisso com responsabilidades), a ampliação de seu vocabulário e o desenvolvimento de habilidades ligadas a esse campo de conhecimento. Portanto, além da construção dos conhecimentos relativos às disciplinas, os autores concluíram que a experiência foi importante para a construção de valores éticos e sociais.

Segundo Oliveira (2004) a horta escolar é um modo diferente de reinventar o fazer pedagógico porque é um instrumento que promove mudanças nos hábitos e atitudes dos alunos em relação à percepção da natureza, pois há possibilidade de se trabalhar diversas atividades, dentre as quais, os conceitos, princípios, o histórico da agricultura, a importância da educação ambiental, a importância das hortaliças para a saúde. Além disso, as aulas práticas permitem que se trabalhem as formas de plantio, o cultivo e o cuidado com as hortaliças. Para Pereira et al. (2008) a horta desenvolve a interdisciplinaridade na escola, desde que elaboradas estratégias de forma didática, auxiliando através de práticas a construção do saber do educando.

Jesus et al. (2011) se propuseram a executar um projeto de horta escolar em meio rural 


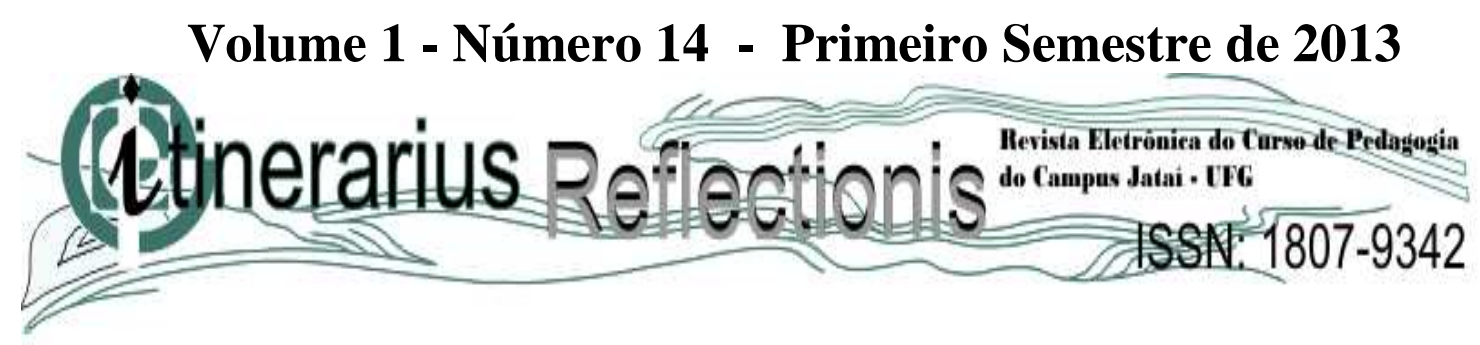

por conta da complexidade de sua abordagem, já que exige a prática interdisciplinar.

Assim, de acordo com diversos autores, com o projeto horta escolar a escola praticamente tem um laboratório ao ar livre dando subsídios às disciplinas de Biologia, Química, Física, Geografia e Matemática.

Para Freire, Feitosa e Santos (2008), como toda prática educativa, o projeto horta escolar é uma ação: intencional, sistemática e planejada, que possibilita aos educandos desenvolver competências e consciência profissional, sem restringir-se ao ensino de habilidades imediatamente demandadas pelo mercado de trabalho. Associado a isso, pode-se trabalhar com diferentes tipos de técnicas de produção de alimentos, como por exemplo, produção orgânica.

Uma horta orgânica inserida num espaço escolar formal ultrapassa os limites do simples plantar e colher, pois se apresenta de forma flexível e articulada a outros projetos pedagógicos, permitindo a interação entre diversos trabalhos e linhas filosóficas na construção de um novo saber ambiental (ANVERSA, 2008). A produção de alimentos saudáveis, não só possibilita uma discussão sobre o modelo produtivo disseminado pelas grandes empresas, controladoras de insumos químicos e sementes geneticamente modificadas, como também possibilita resgatar hábitos passados, como técnicas simples de aproveitamentos de sobras que se faziam hortas nos quintais das residências. Esse reaproximar da natureza pode mudar e/ou desenvolver nos hábitos e na relação com o ambiente.

Portanto, no cotidiano do trabalho em uma horta é possível promover condição de observação, análise, experimentação, reflexão, levantamento de hipóteses, sistematização e outras possibilidades que o contato com o solo promove. É uma excelente oportunidade para o desenvolvimento de conceitos e práticas ambientais, em que o participante é convidado a cultivar experiências únicas onde os resultados sempre surpreenderão (ANVERSA, 2008).

\subsection{A horta escolar como promotora de alimentação saudável}

Pode-se encontrar, numa mesma pessoa, excesso de peso provocado por superalimentação e deficiência de vitaminas, minerais e enzimas por falta de alimentos vivos, 


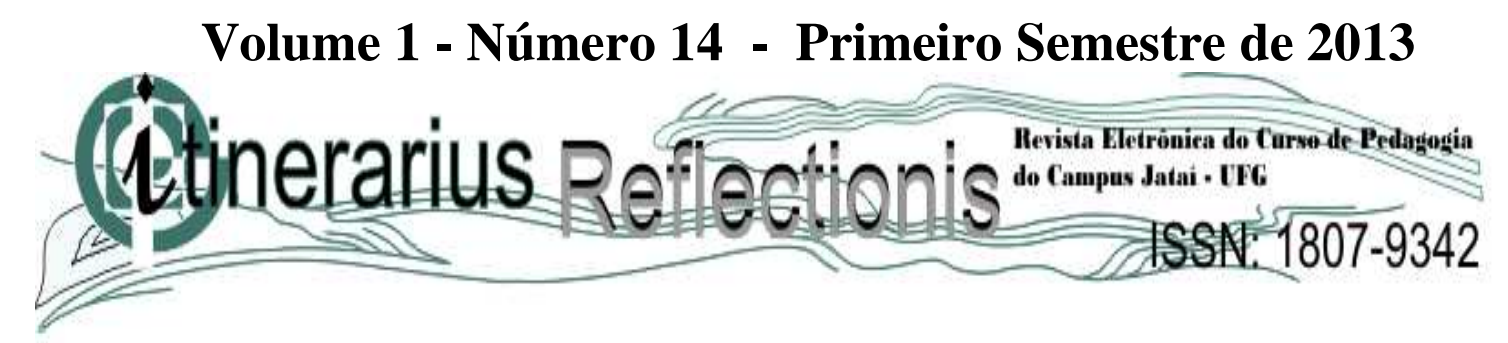

isto é, aqueles que são brotados da natureza, que não passaram por processos de industrialização (SOLEIL, 1992)

Crianças dependentes de alimentos fast-food apresentam, geralmente, rejeição por alimentos saudáveis como hortaliças, legumes e mesmo frutas doces, de acordo com Gonzalez (2008).

A Figura 1 mostra ilustra como, atualmente, as crianças e adolescentes, preferem consumir alimentos inadequados para o crescimento saudável, como aqueles sem muito valor nutritivo ou com exageros nas gorduras e açúcares.

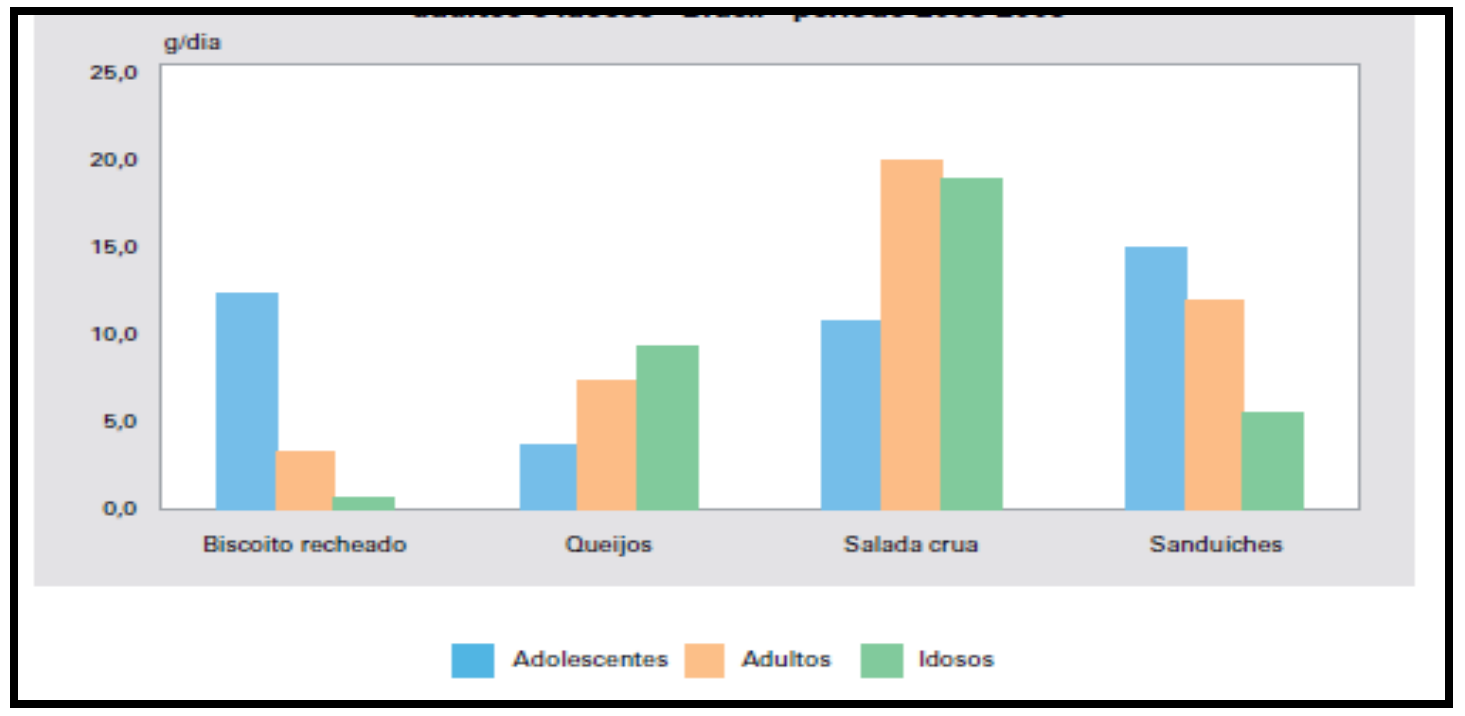

Figura 1 Consumo de itens selecionados na alimentação de adolescentes, adultos e idosos no Brasil, no período de 2008 e 2009.

Fonte: IBGE, Diretoria de Pesquisas, Coordenação de Trabalho e Rendimento, Pesquisa de Orçamentos Familiares (POF), 2008-2009.

Segundo Soleil (1992) quanto maior o nosso contato direto com a natureza e quanto mais comemos alimentos ricos em substâncias vivas, mais nossa vida afetiva se liberta das emoções que nos amarram (medo, julgamentos, raiva, frustrações), mais nossa mente se liberta de suas limitações, mais nossa vida espiritual desabrocha.

Ainda, de acordo com o autor, os alimentos que geram a vida (sementes germinadas e os 


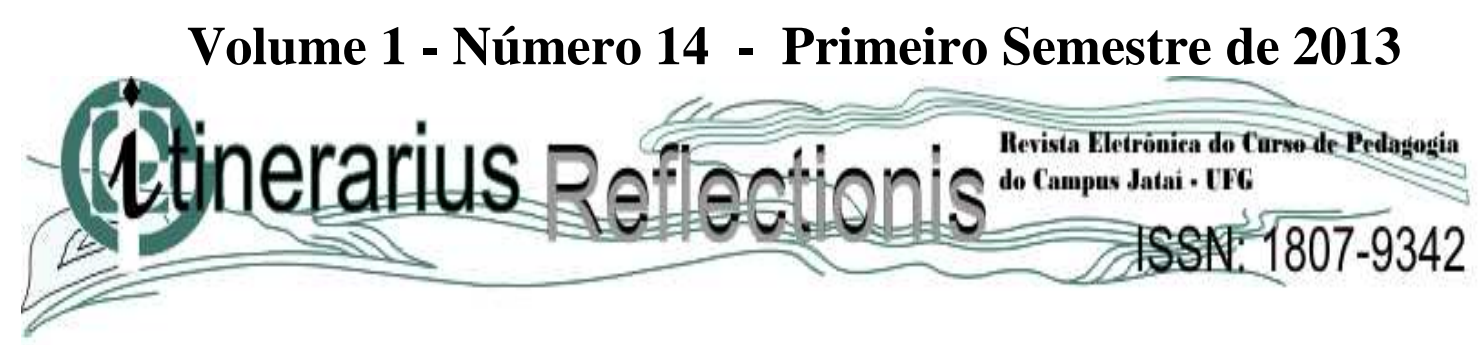

brotos produzidos a partir dos cereais, das frutas oleaginosas, das leguminosas, das ervas e das hortaliças), e os que ativam a vida (frutas, legumes, ervas e hortaliças, leguminosas, sementes oleaginosas e cereais integrais maduros), contêm de forma natural e equilibrada todos os elementos indispensáveis à vitalidade das células. São muito importantes para corrigir os problemas provocados por anos de alimentação desnaturadas (alimentos crus armazenados artificialmente ou não, alimentos refrigerados ou congelados; industrializados) por longos períodos.

O consumo de alimentos desnaturados vem crescendo em grande escala internacionalmente, gerando preocupação com a promoção de saúde, principalmente em crianças e adolescentes na fase escolar. Segundo Bernardon (2011), várias conferências e tratados internacionais foram realizados, como a Conferência de Adelaide e de Jacarta, tendo sido deliberadas ações neste sentido, às quais se relacionam à educação.

O Direito Humano à Alimentação Adequada (DHAA) é parte dos direitos fundamentais à humanidade mas, no Brasil

\footnotetext{
o direito à alimentação somente passou a fazer parte do texto constitucional, no rol dos demais direitos sociais, em 2010, a partir da Emenda Constitucional $\mathrm{n}^{\circ}$ 64, representando o fortalecimento do Sistema de Segurança Alimentar e Nutricional (SISAN) (BERNARDON, 2011).
}

Além disso, a Política Nacional de Alimentação de Nutrição (PNAN) tem como uma das diretrizes a promoção de práticas alimentares e estilos de vida saudáveis. Para isso, é essencial a inclusão do DHAA em todo material educativo.

Uma das principais ações no sentido de promover o DHAA, e como exemplo de transversalidade, envolvendo os temas saúde, educação e alimentação é a implantação de horta escolar. A Portaria Interministerial 1.010 (BRASIL, 2006) resultado de uma parceira entre o Ministério da Saúde e o Ministério da Educação (MEC), para a promoção da alimentação saudável no ambiente escolar, prioriza o desenvolvimento de ações de educação alimentar e nutricional, assim como o estímulo à produção de hortas escolares a fim de desenvolver atividades com os alunos e utilizar os alimentos produzidos na própria escola. 


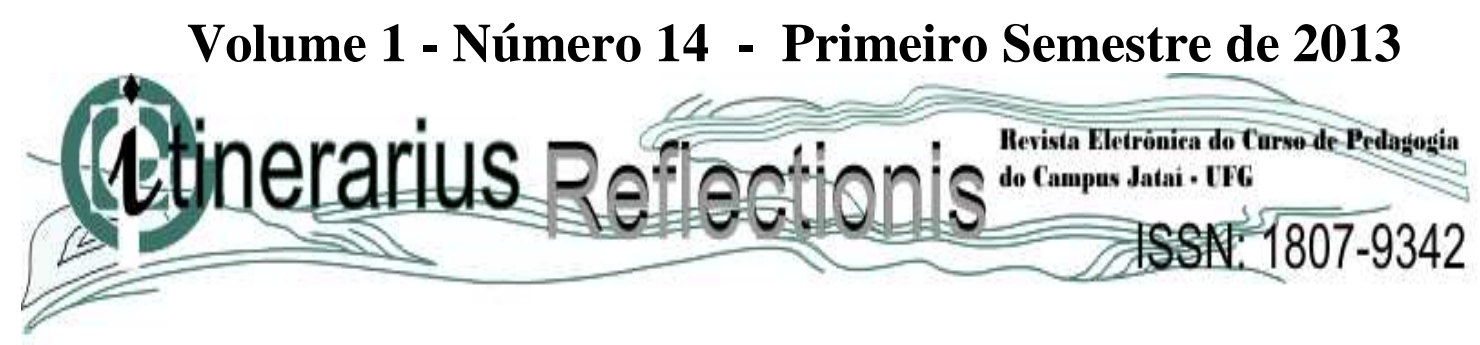

Utilizar a horta escolar como estratégia, visando estimular o consumo de feijões, hortaliças e frutas, torna possível melhorar a dieta das crianças. Como os produtos cultivados na horta escolar são fruto do trabalho dos próprios alunos, passam a ter mais valor e, quando presentes na alimentação, despertam a vontade de experimentar (MAGALHÃES, 2003). Portanto, a horta escolar também pode contribuir para promover a alimentação saudável.

2.3 Horta escolar como promotora da agricultura sustentável

Apesar de ter um modelo que permitiu a grande ampliação da produção de alimentos, a agricultura intensiva, o uso de adubos químicos e as técnicas de conservação da indústria alimentícia são a causa de alimentos desvitalizados e com pouco valor nutritivo (SOLEIL, 1992).

A agricultura sustentável, com baixo nível de aplicação de insumos, está calcada no uso de métodos como rotação de culturas, conservação da lavoura e reciclagem dos excrementos de animais, visando ao controle da erosão, à redução da perda de nutrientes do solo e à manutenção da produtividade (CORSON, 1996).

Segundo Gonzalez (2008), o cuidado com uma horta orgânica é uma forma de arte, integrada a terra e às forças da natureza. Em uma horta, podem-se vivenciar todos os tipos de fenômenos que envolvem a vida: as transformações, as regenerações, as integrações, os ciclos de energia e a percepção de que somente pela devoção em todos os níveis de produção é que podemos chegar à produção de alimentos de alta qualidade.

A horta orgânica é uma maneira de plantar e cuidar das hortaliças com técnicas que não poluem o solo e a água, e não contaminam plantas, plantadores e consumidores. Pode-se dizer que é uma maneira de cultivar imitando a natureza, como por exemplo, a utilização de adubos orgânicos em substituição aos produtos químicos (ANVERSA, 2008). Desse modo, os alunos podem praticar e vivenciar os conteúdos de sustentabilidade que são ensinados em sala de aula.

\section{METODOLOGIA}

A pesquisa desenvolvida trata-se de um estudo de caso, conforme definição de Gressler 


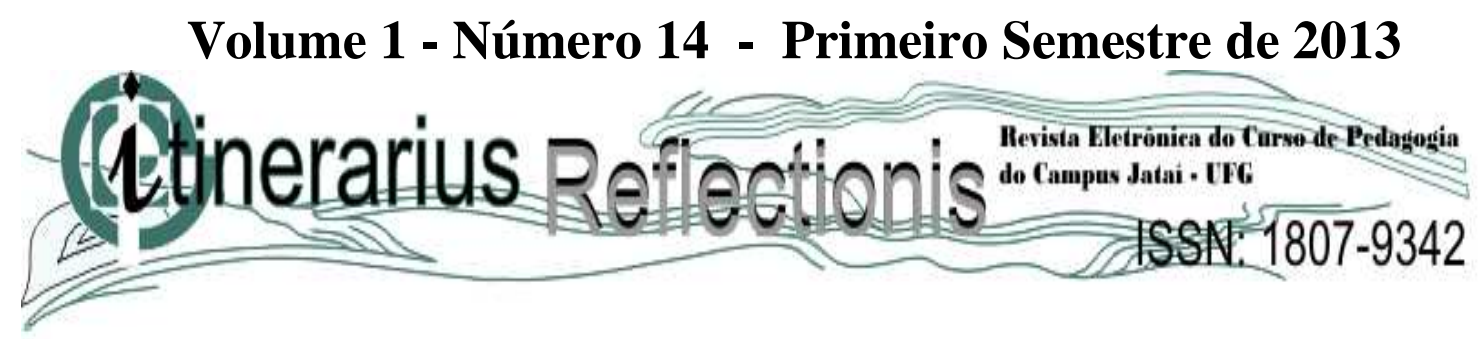

(2003), na medida em que tenta abarcar a totalidade da unidade escolhida para o estudo, por sua especificidade, neste caso, a horta escolar do Colégio Militar de Rio Verde.

Os tipos de estudo de caso adotados na pesquisa podem ser definidos como estudo de caso observacional e de análise situacional e, utilizando os preceitos de Gressler (2003), os passos para desenvolver a pesquisa foram os seguintes:

1) Fase exploratória e interação com o tema, por meio de revisão de literatura sobre horta escolar, englobando horta como estratégia pedagógica, como proposta de alimentação saudável e como projeto de agricultura sustentável. É importante ressaltar que há um grande número de políticas públicas e relatórios de experiências sobre a prática da horta escolar, porém, não foi encontrado estudo mais profundo e analítico acerca do tema.

2) Caracterização do objeto e suas relações internas e externas, etapa em que foram levantados dados quantitativos e observações para a elaboração de uma caracterização do Colégio Militar de Rio Verde, bem como procedeu-se à leitura do Projeto de Horta implantado neste.

3) Definição do problema e hipótese: diante caracterização do Colégio e da leitura do Projeto, pôde-se delimitar melhor estudo, enunciando os quesitos que deveriam ser pesquisados.

4) Desenho da pesquisa, com a construção dos instrumentos de coleta de dados: entrevista e observação.

5) Coleta de dados durante o ano de 2011. Em se tratando de um estudo de caso, esta etapa é fundamental para buscar todas as circunstâncias, peculiaridades e pontos de vista de todos os envolvidos, porém esta fase teve certo prejuízo, principalmente em relação aos alunos envolvidos, pois somente dois alunos continuavam participando do Projeto de Horta.

6) Organização das informações e análise. Nesta etapa, procedeu-se à avaliação, por meio de uma confrontação entre o que constava no Projeto, objetivos e metodologias, e a sua realização na escola.

7) Relatório dos resultados: a confrontação da fase precedente permite não só avaliar, como identificar pontos positivos, negativos, falhas e sucessos obtidos com a realização do Projeto. Além disso, permite confrontar os resultados obtidos neste projeto com as experiências descritas em outros locais e realidades. E, por fim, permite que sejam feitas sugestões para a continuidade 


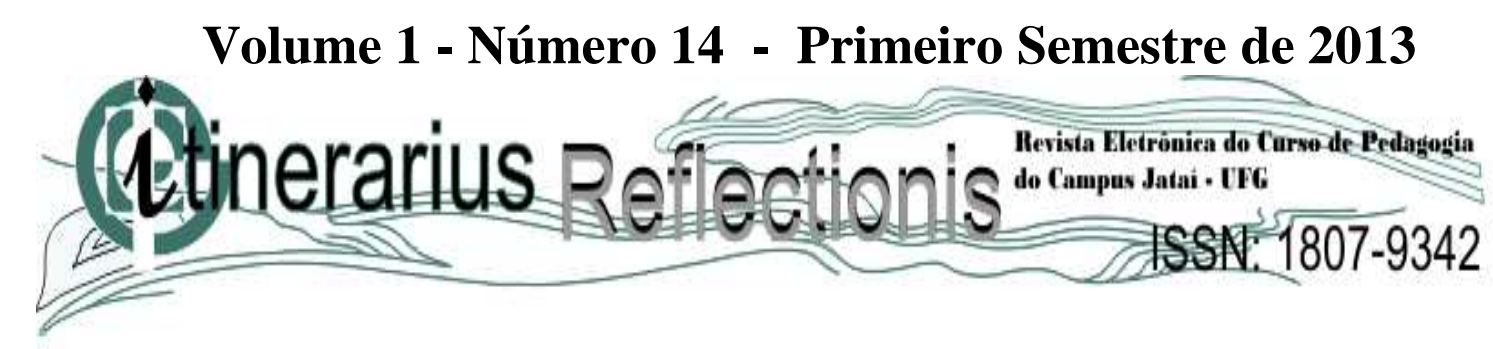

do projeto.

\subsection{Caracterização do público alvo}

Rio Verde é um dos municípios mais populosos do estado de Goiás. Hoje, com $8.379,661$ km² de extensão territorial e aos 163 anos de existência, Rio Verde conta com mais de 180 mil habitantes (IBGE, 2011), sendo um pólo econômico importante do Centro-Oeste brasileiro.

O Colégio Militar Carlos Cunha Filho foi inaugurado no dia 29 de Janeiro de 2002, criado através da Lei 14.050, de 21 de Dezembro de 2001 e instalado nas dependências do $2^{\circ}$ Batalhão da Polícia Militar, na cidade de Rio Verde-GO.

O colégio conta com 1.236 alunos sendo 17 turmas de ensino Médio no turno matutino e 18 do Ensino Fundamental no turno vespertino, salas climatizadas e apoio psicossocial ao estudante.

No aspecto estrutural, o Colégio conta com uma quadra coberta Poliesportiva, laboratório de Ciências, laboratório de Informática, um moderno Centro de Execução de Projetos, ampla biblioteca, banda de música, auditório com data show, sala para professores, galeria de troféus, paisagismo, além de ter um moderno sistema de monitoramento das salas de aulas e corredores, através de câmeras. Conta ainda com um refeitório para servir os funcionários e professores.

No aspecto pedagógico, o grupo é formado por 36 professores, 4 coordenadoras, e outros 41 funcionários da merenda, biblioteca, limpeza e secretaria. No disciplinar conta com 12 militares.

O público alvo é formado por um grupo heterogêneo que vai desde os mais carentes até os de maior poder aquisitivo. Para pertencer ao corpo de discentes do Colégio da Polícia Militar Goiás (CPMG) é necessário passar por um sorteio, que é aberto mediante Edital Público com portaria emitida pelo Comandante Geral da PM/GO, de acordo com o número de vagas existentes em cada unidade do CPMG.

Podem participar do concurso candidatos dependentes de civis ou dependentes de militares, sendo que 50\% (cinquenta por cento) das vagas são destinadas aos filhos de militares e 


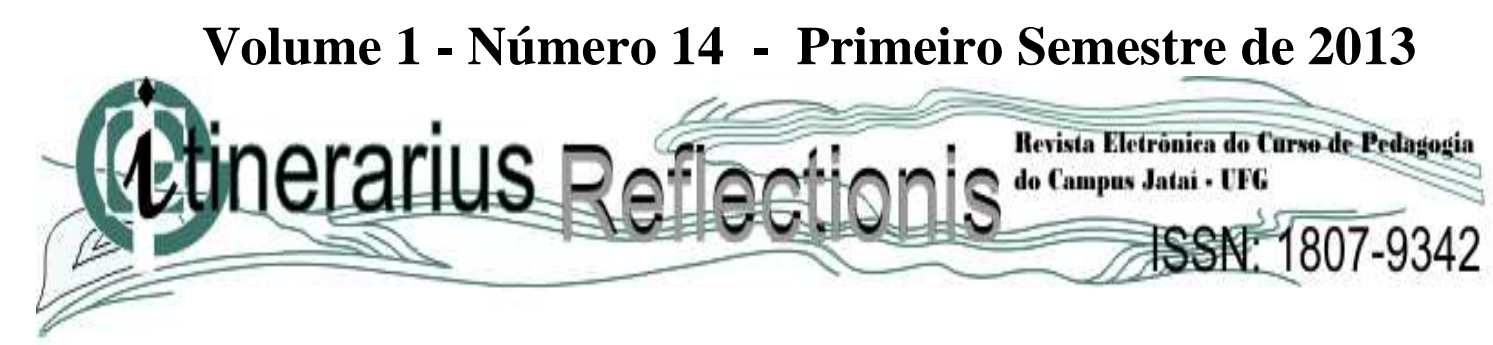

$50 \%$ (cinquenta por cento) destinadas aos filhos de civis, ou seja, dependentes de civis concorrem com dependentes de civis e dependentes de militares concorrem com dependentes de militares. $\mathrm{O}$ sorteio é feito na própria escola com a presença de todos os inscritos e seus familiares e também de funcionários da instituição, conforme número de vagas oferecido para cada série.

\title{
4 RESULTADOS E DISCUSSÃO
}

\subsection{Reconhecimento do projeto horta}

A professora responsável pela execução do projeto horta escolar Maria Luiza Morais Evangelista é graduada em Geografia e atua como professora de Geografia nos $1^{\mathrm{os}}$ e $2^{\mathrm{os}}$ anos do Ensino Médio.

O reconhecimento inicial foi feito a partir da leitura do Projeto escrito por Evangelista (2011). Assim, será feita uma descrição do projeto escrito e utilizar-se-á, por vezes, os verbos no futuro.

O projeto horta mandala tem como objetivo

\begin{abstract}
desenvolver práticas na produção de hortaliças e galinheiros que possam conscientizar o alunado da importância da alimentação saudável, valorizando a pesquisa de campo e o trabalho em grupo, na formação crítica da construção coletiva do conhecimento, sempre priorizando o manuseio do meio ambiente de forma sustentável (EVANGELISTA, 2011).
\end{abstract}

Consta no Projeto que, para sua execução, os alunos deveriam trabalhar em turno inverso de suas aulas, sendo orientados pelo professor nas pesquisas, aulas práticas e teóricas, de forma periódica.

Com o objetivo de realizar todas as atividades com técnicas adequadas para a produção orgânica foram realizadas parcerias com a EMATER (Empresa de Assistência Técnica e Extensão Rural de Goiás), Fesurv (Universidade de Rio Verde) e Instituo Federal Goiano, com orientações dos profissionais destas instituições. 


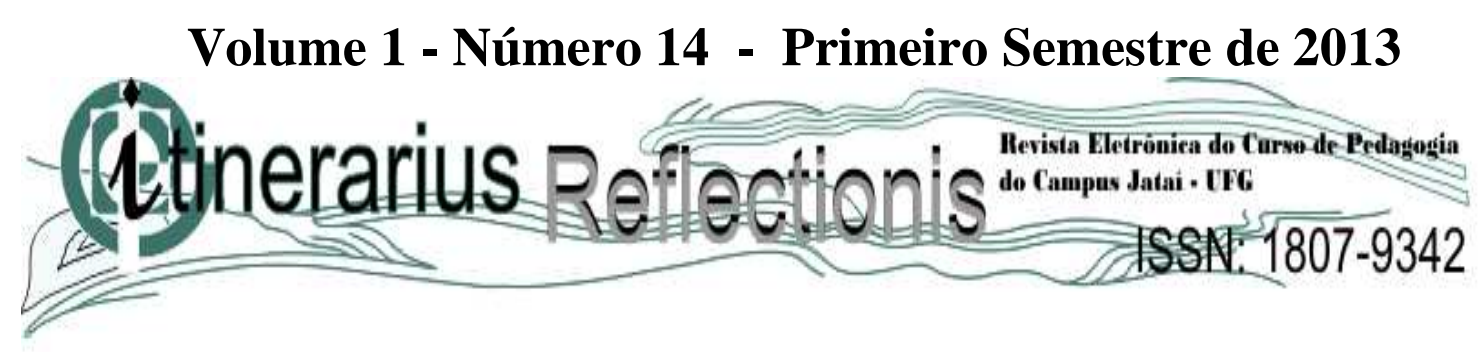

Consta ainda, no projeto, que os alunos farão pesquisas em livros, Internet e na biblioteca da escola; serão orientados no manuseio da terra com os devidos métodos e cuidados; haverá acompanhamento durante todo o ano letivo conforme o calendário; haverá dedicação de um funcionário do Colégio aos afazeres da horta durante ausência dos alunos. Por fim, quando for possível serão organizadas apresentações em seminários, palestras, oficinas, amostras e/ou minicursos.

Para início do plantio será feita aquisição de mudas da horta da Fesurv e do IF Goiano, e realizado o plantio de flores em volta da área, para atrair os insetos isentando as hortaliças de serem danificadas. Haverá plantio de bananeiras no canto da área, com o objetivo de produzir além das hortaliças frutas na medida do possível. Replantio e plantio de novas plantas medicinais entremeando as hortaliças.

O quadro de horário desenvolvido para execução do projeto foi da seguinte forma: terça-feira e quarta-feira das $13 \mathrm{~h}$ às $18 \mathrm{~h}$ e quinta-feira, das $13 \mathrm{~h}$ às $14 \mathrm{~h} 40 \mathrm{~m}$. O projeto apresentou 25 vagas a serem ofertadas para a participação de alunos do Ensino Médio. O critério utilizado na escolha dos participantes do projeto é a necessidade de reforço motivacional, para alunos com notas abaixo da média.

Por fim, os alunos participantes foram avaliados continuamente a partir dos trabalhos realizados, da observação, das atitudes e interesse nas aulas teóricas; da participação ativa nas aulas práticas e da busca de informações concretas referentes ao manuseio do solo e das plantas.

\subsection{Avaliação da execução do Projeto}

Durante as atividades realizadas na horta foram produzidos nove relatórios, nos quais a professora Maria Luiza relata o trabalho prático executado pelos alunos. Através da leitura e análise desses relatórios, bem como de observações presenciais feitas durante o trabalho da mesma, pôde-se avaliar a execução do projeto.

No primeiro semestre de 2011 foi feita uma apresentação do projeto aos alunos interessados em participar do mesmo; a professora do curso de Agronomia da FESURV Regina 


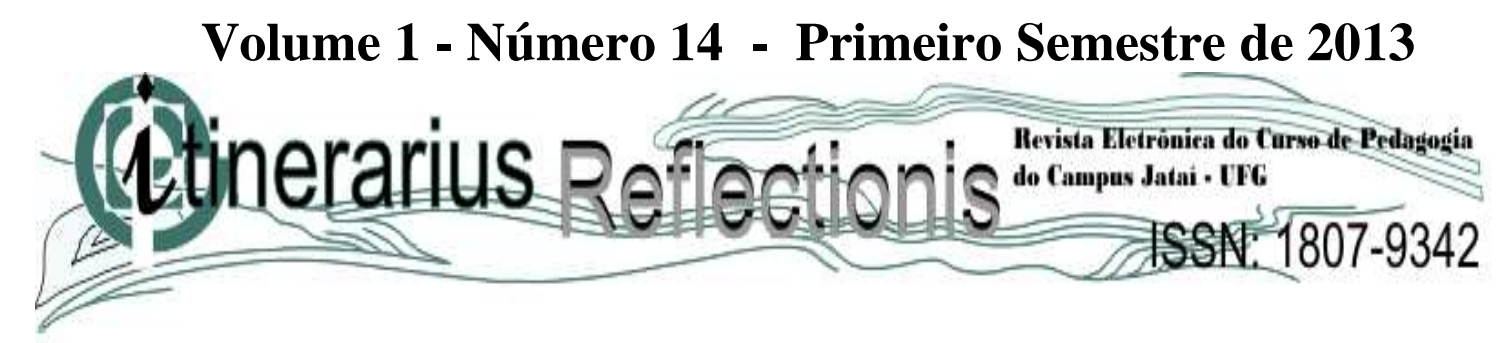

Moreira Vilarinho Barbosa, como parceira do projeto, participou explicando aos alunos alguns conceitos básicos da produção orgânica de hortaliças. Os alunos participaram com entusiasmo dessa primeira etapa.

Após receberem várias informaçoes foram iniciadas as tarefas como: preparar canteiros para semeadura, semearam várias espécies de hortaliças, irrigação dos canteiros, limpeza na entrada da área.

Quinze dias após o plantio e tendo os cuidados necessários para o desenvolvimento da horta , os alunos puderam contemplar o bom crescimento das hortaliças. Nesse momento foram discutidos assuntos sobre horta, momento em que os alunos pesquisaram e puderam fixar no caderno as informações.

Os alunos acompanharam a produção de inseticidas naturais para combater as lagartas, tais como: água com sabão em pó, inseticida de mamona com álcool, cebola com água, água com pimenta, além dos cuidados diários realizados na horta, limpeza dos canteiros tirando pragas e alguns lixos inorgânicos, irrigação, retirada de mudas. Fizeram combate com inseticidas naturais produzidos por eles mesmos.

Na Figura 2 são apresentados alguns dos aspectos desta primeira fase.

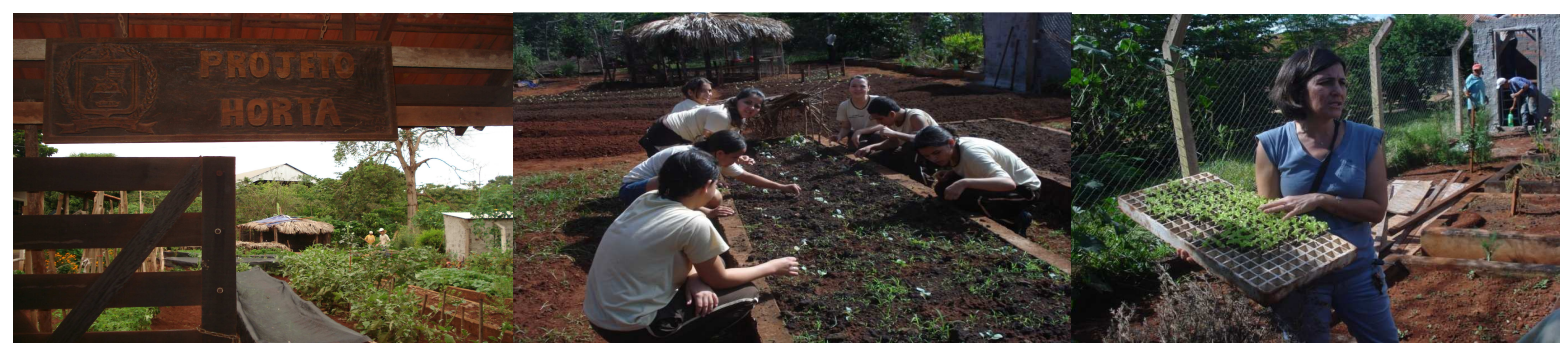

Figura 2 Imagens da execução do projeto do primeiro semestre de 2011.

No segundo semestre de 2011, segundo relato da professora, foi feito novo recrutamento para definir quem participaria do projeto. Após a defininiçao já iniciaram o trabalho, pois já havia algumas espécies de hortaliças a serem colhidas como alface, repolho, couve, cenoura, beterraba. Os alunos realizaram novas pesquisas, tendo assim mais conhecimentos para utilizar 


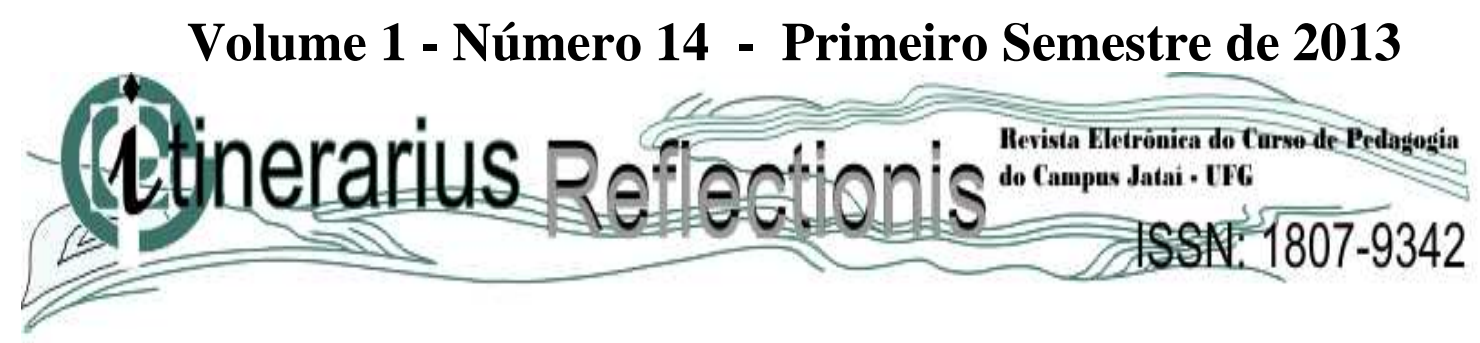

na prática. $\mathrm{Na}$ alface plantada em setembro foi utilizado sombreiro para protegê-la do sol intenso e chuvas que estragam suas folhas. Como experimento, foi plantado um canteiro de alface sem sombreiro, para verificar-se qual seria o resultado em relação aos que foram cobertos. Com apoio de professores de Biologia, obteve-se resultados positivos no combate à novas ervas daninhas que foram surgindo. Como, por exemplo: foi sugerido que utilizasse: 100 $\mathrm{ml}$ de óleo, $100 \mathrm{ml}$ de detergente e completasse o restante de um litro com água.

A produção de plantas medicinais foi muito produtiva favorecendo uma boa colheita. Parte dessas plantas foram oferecidas ao Movimento Popular de Rio Verde (MOPORV), para a produção de remédios naturais.

Nos últimos meses do semestre a horta proseguiu com seu desenvolvimento normal, mas apenas dois alunos permaneceram firmes no trabalho, devido ao fato de as atividades serem realizadas no contraturno e a escola ficar distante das principais linhas de ônibus dificultando o deslocamento dos demais integrantes do grupo selecionado e também devido a escolha por outras atividades no mesmo período.

Atendendo àquilo que constava na metodologia do Projeto horta, foi realizada uma palestra sobre "Sistema Integrado de Produção Sustentável: Desafios e perspectivas", organizada pela Secretaria Municipal de Agropecuária e Meio Ambiente de Rio Verde em conjunto com a Cooperativa Goiás Orgânicos, Embrapa e Fesurv.

Assim, de modo geral, os relatórios mostram um bom desenvolvimento e alcance dos objetivos propostos inicialmente, no Projeto, mesmo com a desistências de alunos.

A execução do Projeto também pode ser avaliada por meio da análise das percepções dos envolvidos no processo. Para a professora responsável, o desenvolvimento do projeto trouxe pontos positivos e negativos. Os pontos positivos, apontados por ela, são:

\footnotetext{
Oportuniza tanto para os alunos como para o professor um laboratório de buscas e aprendizagem com as informações e a prática. Valorização dos produtos orgânicos a partir do momento que vivencia a qualidade em comparação com os convencionais. Incentiva a valorizar mais o meio ambiente não degradando com produtos químicos e manejo do solo descriminado.
} 


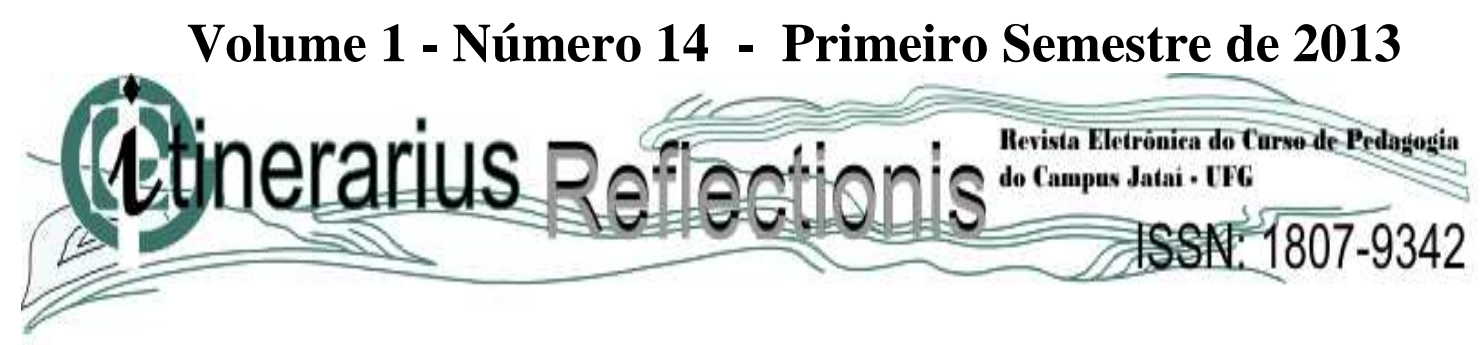

Já os pontos negativos, são: "Falta de valorização de muitos alunos, buscam apenas ser recompensado com uma nota. [Falta de] motivação dos pais para que os alunos permaneçam participando do projeto. Transporte difícil devido à escola ficar distante das principais linhas de ônibus."

Já para os alunos, o projeto "beneficia tanto os alunos quanto a escola, ao participar da horta estamos contribuindo para melhor qualidade dos alimentos da merenda escolar." (Aluno A).

"Acho muito bom, pois, além de aprendermos várias coisas sobre horta, a professora dá um incentivo ao aluno premiando com 1 ponto." (Aluno B)

\subsubsection{Quanto às práticas pedagógicas}

Na entrevista realizada com o Diretor do Colégio Militar, foi dito que,

como o projeto esteve parado algum tempo, pouco a pouco está sendo feito um trabalho de envolvimento em atividades práticas, [como]:

- visitas in loco à horta

- mencionar nas disciplinas o processo de produção, preocupação com o meio ambiente, água, etc.

- envolver professores de diversas disciplinas em experiências práticas.

Segundo a professora, Maria Luiza "quando há necessidade de desafiar, combater, eliminar algum inseto e é preciso testar várias inseticidas naturais para resolver o problema, já houve casos dos alunos pesquisar voluntariamente ou recorrer pessoas experientes para dar informações que poderiam enriquecer o estudo."

Segundo a Anversa (2008) com a introdução da Educação Ambiental, enquanto tema transversal, e em alguns casos como disciplina específica no currículo escolar, foi necessária a criação de ambientes mais flexíveis e, principalmente, a formação de profissionais com uma leitura epistemológica dos problemas educacionais, ambientais e dos novos paradigmas emergentes capazes de gerar um novo saber ambiental. Como já foi dito no item 2, a horta vem ilustrar a criação do ambiente favorável à prática da Educação Ambiental, enquanto um novo saber, seja no contexto escolar ou em contextos onde a educação se dá informalmente. 


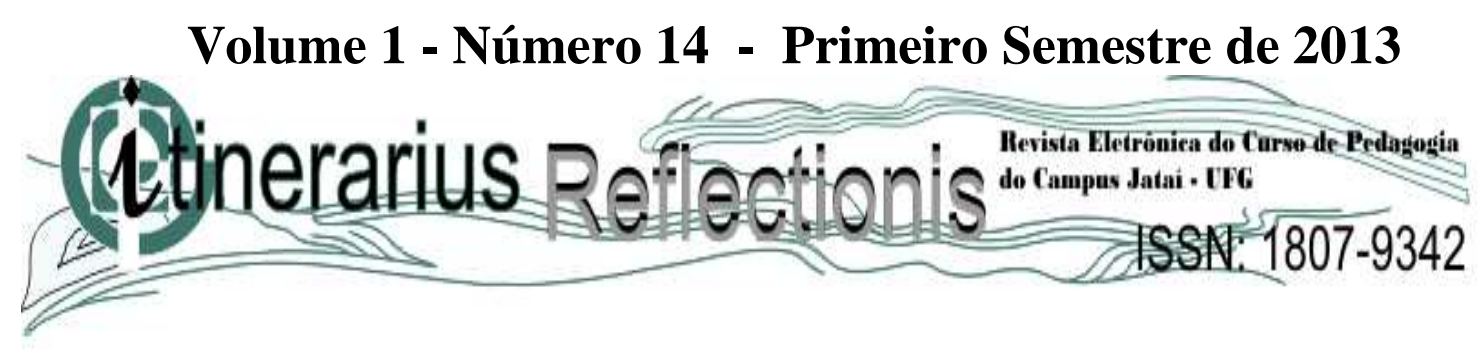

Nesse sentido, é evidente o empenho da professora, e até mesmo do diretor. Porém, a complexidade e a interdisciplinaridade necessária à prática pedagógica por meio da horta escola, não estão presentes no Colégio Militar de Rio Verde.

A professora de Geografia, Maria Luiza, coordenadora do projeto, levou seus alunos à horta para aula de campo, usando-a como prática pedagógica pode discutir conteúdos como agroecossistemas orgânicos e sustentáveis sem uso de agrotóxicos e inseticidas. Foi explicado aos alunos sobre o combate dos parasitas com a inseticida natural mencionado acima; dias depois uma aluna procurou a professora para saber a receita, porque a sua avó tem uma horta e foi atingida pelo mesmo parasita. Visualiza-se a continuidade do projeto para além dos muros da escola.

Durante o período de observação do trabalho, não se percebeu a utilização da horta como instrumento pedagógico por outros professores, embora a professora Maria Luiza tenha comentado que a professora de Língua Inglesa levara os alunos até a horta durante uma de suas aulas.

\subsubsection{Quanto à melhora no aprendizado}

Na apreciação do Diretor do Colégio "Foi observada junto à professora encarregada do projeto horta uma melhora no rendimento escolar de seus alunos."

Segundo a professora: "Os alunos que participaram efetivamente, sim, houve melhoras, mas no sentido da relação professor $\mathrm{X}$ aluno, interesse pela natureza e valorização dos produtos naturais. Um aluno até plantou uma horta na propriedade dos seus pais."

Questionados sobre a melhora no aprendizado dos alunos, as respostas foram as seguintes: "Sim, em Geografia. Aprendemos a tratar o solo e fazer um bom plantio sem o uso de agrotóxico e outros tipos de química" (Aluno A). Já o aluno B: "Geografia, estuda na apostila sobre produtos orgânicos e etc, e aprende um pouco mais na horta".

Desse modo, ainda que fique claro que a participação parece estar condicionada à nota, os alunos perceberam melhora no aprendizado. 


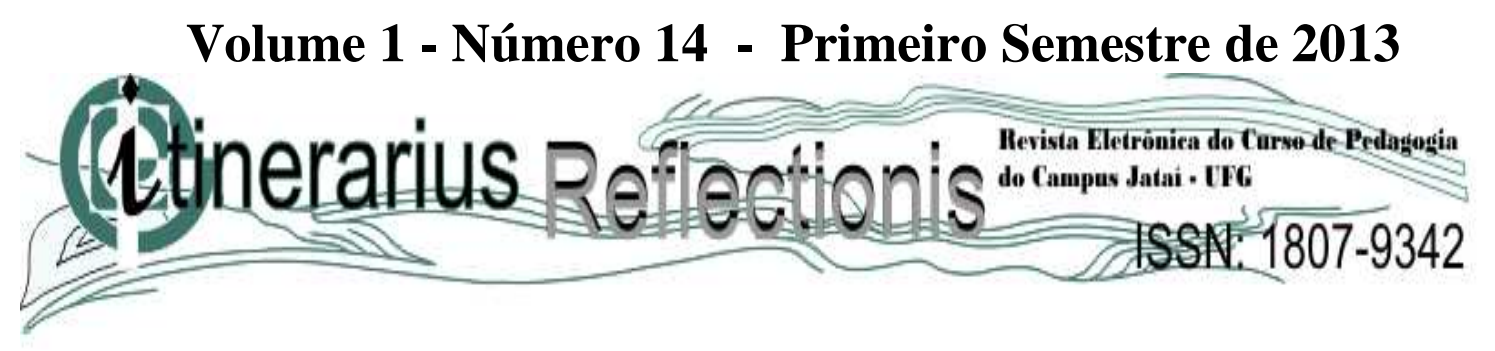

Em outros momentos das entrevistas, também é perceptível: “[...] isso me proporciona maior conhecimento na arte de plantar e colher" (Aluno A). “[...] me ensina várias coisas como plantar e colher" (Aluno B).

\subsubsection{Aspecto alimentar e saúde}

Não há um monitoramento quantitativo sobre este item. De acordo com a professora Maria Luiza "Se melhoraram não tem informação precisa, porém despertou preocupação com a qualidade com a maioria dos alimentos que são consumidos."

Já os alunos, quando questionados sobre estes itens, afirmaram que seus hábitos alimentares, assim como suas saúdes, melhoraram, “[...] porque não conhecia essa variedade de alimentos, e agora conheço vários tipos de verduras e legumes. [...] me sinto mais forte e saudável” (Aluno A).”“ [...] passei a comer vários legumes que não comia antes da horta [...] a professora entrega vários legumes para levar para casa e incentivando nós a comer legumes e verduras."(Aluno B)".

Na Figura 3 são apresentados aspectos dos legumes e hortaliças cultivados na horta.

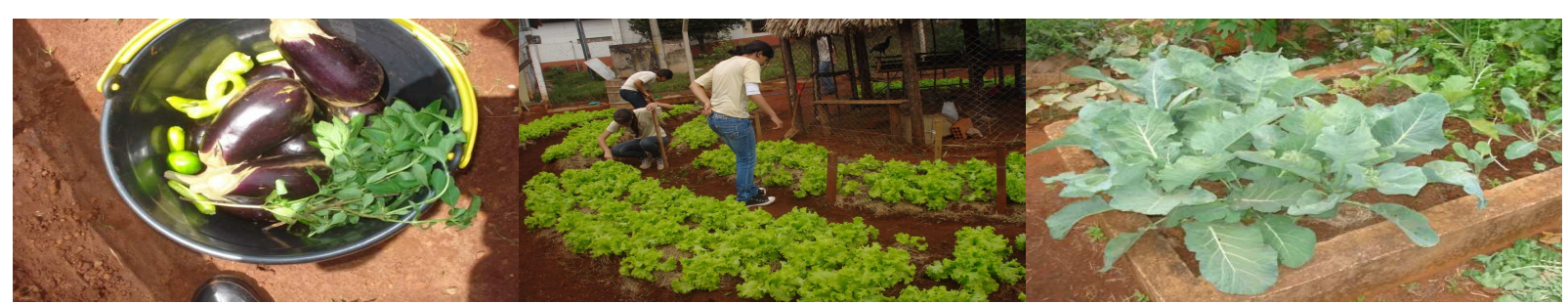

Figura 3 Legumes e hortaliças produzidos na horta.

\subsubsection{Dificuldades}

O projeto teve início com alunos de duas turmas de $1^{\circ}$ ano do Ensino Médio, sendo 10 alunos de cada turma. Mas, no final das atividades no ano de 2011 permaneceram somente dois alunos.

Segundo dados levantados junto à professora, vários fatores são responsáveis por este 


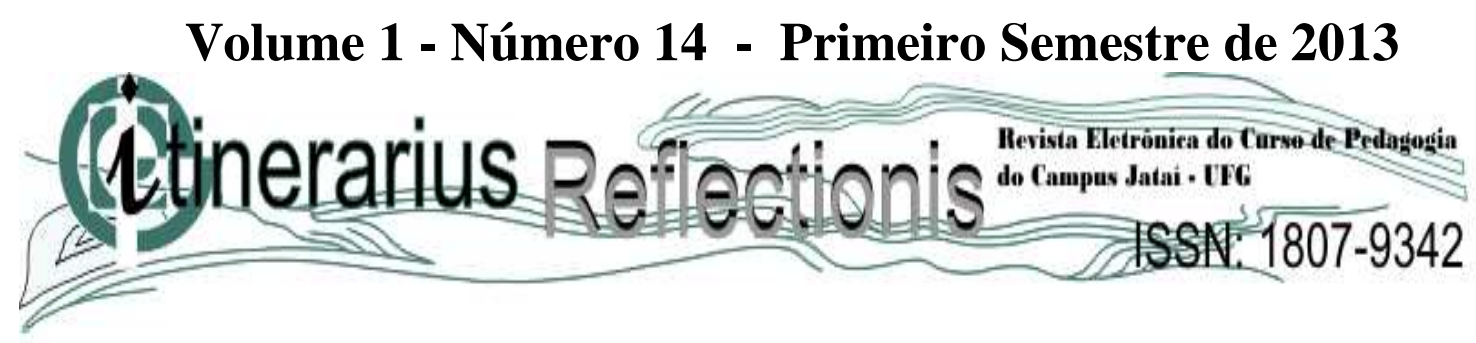

número surpreendente: aluno que conseguiu emprego, necessidade de fazer uma atividade física e não foi possível conciliar as duas coisas, desânimo devido à escola ser muito distante da cidade e a dificuldade de transporte.

$\mathrm{Na}$ percepção do diretor, as principais dificuldades encontradas no desenvolvimento do projeto, foram:

- combater as pragas e ervas daninhas;

- maior comprometimento dos alunos;

- distância da escola com a cidade, dificultando o transporte.

- saída dos alunos devido a empregos, cursinhos e maior interesse pela prática de esportes.

Resultados muito parecidos encontraram Jesus et al (2011); ao avaliar um projeto de horta escolar no meio rural do sertão pernambucano puderam

[...] concluir que a transversalidade do ensino ainda está no papel, no dia-dia das escolas de área rural. A temática proposta foi considerada pelo grupo de pesquisadores assim como pela direção da escola como adequada, porém pode-se perceber que, devido à baixa auto-estima dos professores e por se tratarem de professores, em grande maioria em final de carreira e por profissionais contratados, respondem a fraca adesão dos resultados.

Resultado diverso encontrou Guerra (2002), no município de Angra dos Reis:

A qualidade da participação, o interesse e o desempenho dos alunos nas aulas aumentou consideravelmente, sendo fundamental destacar o espetacular desempenho dos monitores durante as visitas das turmas de $1^{\circ}$ segmento à horta. Alunos que no início do ano não mostravam interesse ou tinham dificuldade de relacionamento com outros colegas e com professores, mostraram uma desenvoltura extraordinária nos momentos de visitas de outras turmas. Explicavam, orientavam sobre a construção de hortas domésticas e sobre a importância dos alimentos com extrema clareza.

Devemos também destacar que, apesar das dificuldades enfrentadas pela maioria dos alunos envolvidos, o sucesso na doação/troca de alimentos por mudas, com envolvimento das famílias dos estudantes foi também um dos parâmetros que nos permitiu avaliar o sucesso de nossa proposta solidária.

Este autor conclui

Apesar das dificuldades enfrentadas, podemos sem a menor sombra de dúvidas ratificar a importância que uma horta escolar, pedagogicamente explorada e não pensada apenas como um espaço produtor de alimentos, tem para a vivificação do 


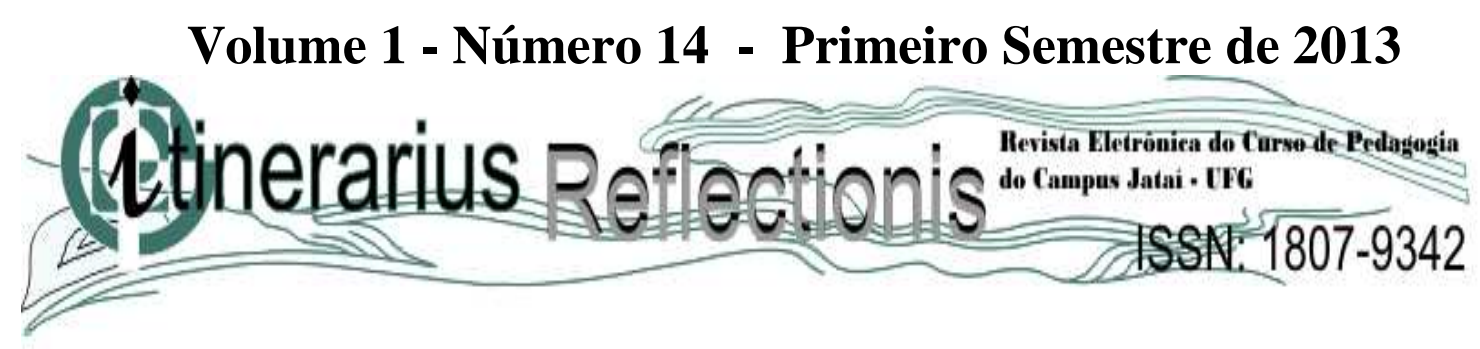

currículo, para a consolidação de trabalhos interdisciplinares e a construção de atitudes de cidadania.

Certamente, ainda temos um longo caminho a percorrer. Mas, em nossa unidade escolar, pelo menos com os professores e turmas envolvidas, conseguimos graças ao projeto Horta solidária: detonar um movimento de resgate da ludicidade - do prazer associado à construção do conhecimento -, ampliar o diálogo entre as disciplinas (interdisciplinaridade), entre os diversos segmentos (alunos, professores, direção, cozinheiras, zeladores, responsáveis etc) e construir uma ação concreta de solidariedade.

A horta escolar, certamente, ainda nos possibilitará a colheita de muitas folhas, frutos e sementes. Sementes estas que, em contato com o fértil solo dos nossos desejos, germinarão trazendo a possibilidade de um mundo mais solidário, justo $\mathrm{e}$ ambientalmente saudável. (Guerra,2002)

\subsection{Proposições}

$\mathrm{Na}$ entrevista realizada com o Diretor, ele sugeriu "buscar mais conhecimentos através de pesquisas com projetos semelhantes, realizadas por profissionais entusiastas deste processo de produção que agrega melhor qualidade de vida e formação de vida."

A partir das observações realizadas, pode-se verificar que o trabalho teve um bom desenvolvimento, mas é preciso encontrar estratégias para resgatar a participação dos alunos. Se os alunos do Ensino Médio estão realmente com o tempo limitado para participar no contraturno, poderia - se buscar de outra forma de participação, dando a oportunidade de participarem durante o turno normal de aulas. Além disso, o CPMG pode desenvolver o projeto horta também com alunos do Ensino Fundamental, pois eles estão em uma fase onde tudo é interessante, querem descobrir novas coisas e demonstram grande interesse em participar.

Pôde-se observar o interesse dos alunos em estar presente na horta fazendo parte da equipe, aprendendo preparar a terra, semear, cuidar e colher as hortaliças, chegando a ponto de querer degustar alguns tipos de hortaliças ali mesmo, na horta. Isso mostra que, apenas, é necessário mais incentivo a alunos e professores.

O conhecimento e a ação participativa na produção e no consumo principalmente de hortaliças - fonte de vitaminas, sais minerais e fibras - despertam nos alunos mudanças em seu comportamento alimentar, atingindo toda a família, conforme relata Turano (1990). 


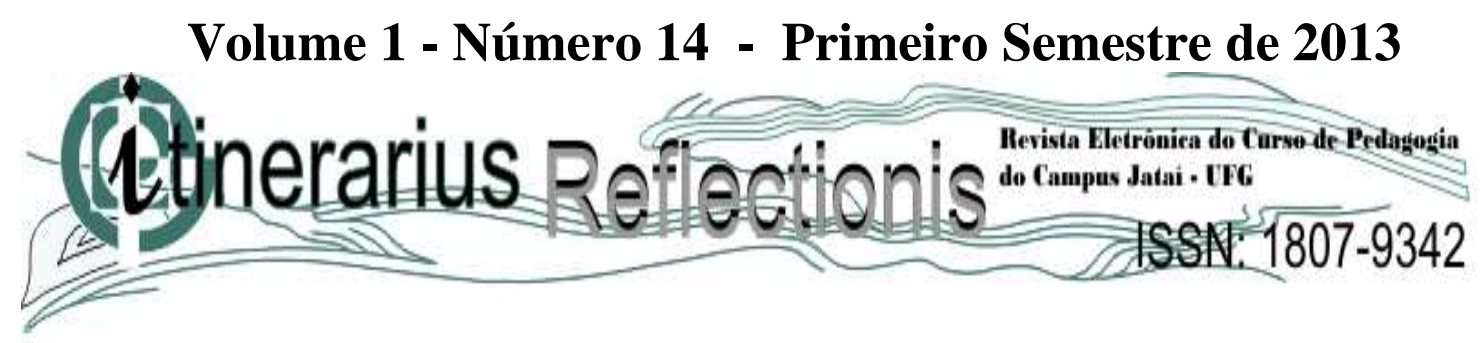

Além da professora responsável, da disciplina de Geografia, pode haver participação de professores de outras disciplinas como por exemplo; Língua Portuguesa, Artes, Ciências, Biologia, etc, desenvolvendo atividades sobre o tema horta escolar.

Como sugeriu Morgado (2006), poderia ser feita a confecção de materiais educativos (livros de receita, cartazes, pinturas e textos coletivos); atividades lúdicas (criação de personagens e apresentação de teatros); reciclagem de resíduos sólidos (compostagem, coleta seletiva e oficinas de reciclagem artística); mutirões com a comunidade escolar para a manutenção do ambiente da horta.

Além disso, poderiam realizar oficinas culinárias, para fazer saladas, sopas, sanduíches naturais e sucos mistos de vegetais e frutas; elas são estratégias muito eficazes para promover uma melhoria na aceitabilidade desses alimentos, os quais, embora muito nutritivos, costumam ser os campeões de rejeição (MAGALHÃES, 2003).

Por fim, sugere-se levar os alimentos para a sala de aula, tentando, de algum modo, transformá-los em elemento pedagógico, fazendo com que as crianças participem das ações de educação alimentar desenvolvidas e não fiquem como meros espectadores (MORGADO, 2006).

Para tudo isso, porém, é muito importante que haja um consenso e uma preparação, primeiro, do corpo docente, com auxílio da Coordenação Pedagógica do Colégio.

\section{CONCLUSÕES}

Por meio deste trabalho foi possível avaliar o projeto de horta escolar, desenvolvido no CPMG, que apresentou resultados positivos e negativos. Através da revisão de literatura, entrevistas e observação, pôde-se perceber que o trabalho prático em uma horta permite resgatar nos alunos a consciência da importância de preservação do meio ambiente, levando-os a desenvolver trabalhos com materiais orgânicos, o que contribui para que haja uma melhoria na aprendizagem de disciplinas relacionadas ao tema, e dá subsídios também a outras disciplinas no desenvolvimento de atividades lúdicas. 


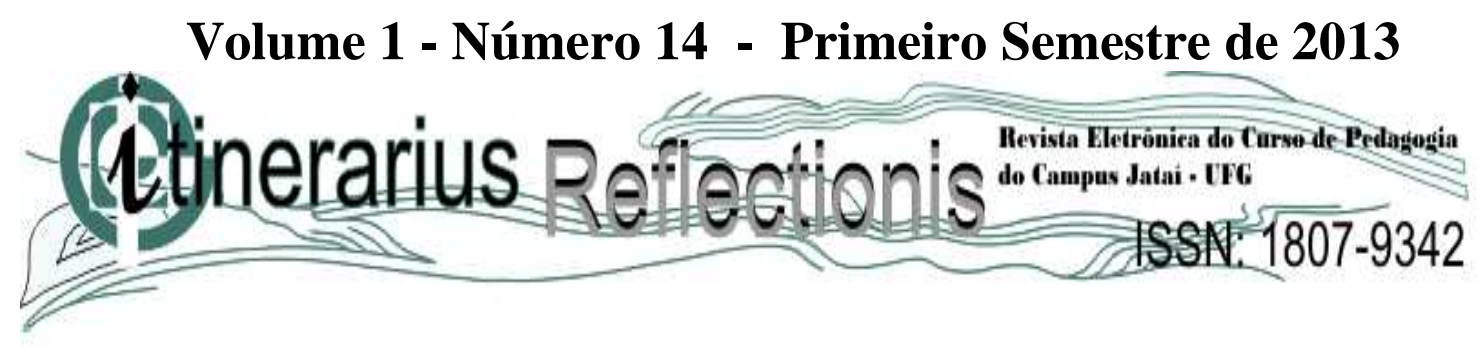

Através dos resultados obtidos na pesquisa, conclui-se que a horta escolar no âmbito educativo é um excelente instrumento pedagógico, que leva os alunos à construção coletiva do conhecimento sempre priorizando o manuseio do meio ambiente de forma sustentável.

\section{REFERÊNCIAS BIBLIOGRÁFICAS}

ANVERSA, V. A. Mãos à horta! Trabalhando com hortas orgânicas para a aplicação de conceitos da Educação Ambiental na escola. Niterói - RJ - 2008. CENTRO UNIVESIDADE PLÍNIO LEITE, cartilha elaborada a partir da dissertação de Mestrado.

BERNARDON, R. Horta escolar no Distrito Federal: Instrumento de Promoção da Alimentação Saudável? Brasília 2011. Dissertação apresentada ao programa de Pós Graduação em Nutrição Humana da Faculdade de Ciências da Saúde da Universidade de Brasília.

BRASIL. Portaria Interministerial $\mathrm{n}^{\circ} 1.010$, de 8 de maio de 2006. Institui as diretrizes para a Promoção da Alimentação Saudável nas escolas de Educação Infantil, fundamental e nível médio das redes públicas e privadas, em âmbito nacional. Diário Oficial da União, Poder Executivo, Brasília/DF, 9 maio 2006.

CORSON, W. H. Manual global de ecologia: o que você pode fazer a respeito da crise do meio ambiente. 2. ed. São Paulo: Augustus, 1996. 413 p.

EVAngelistA, M. L. de M. Horta Mandala. Projeto. Colégio da Polícia Militar de Goiás, unidade Carlos Cunha Filho. Rio Verde - GO, 2011.

FREIRE, J. L. O. et al; Horta escolar: uma estratégia de aprendizagem e construção do cidadão. Caderno Temático / Secretaria de Educação Profissional e Tecnologia. $\mathrm{n}^{\circ}$ 20. Março 12008 .

GRESSLER, L. A. Introdução à pesquisa: projetos e relatórios. São Paulo: edições Loyola, 2003.

GUERRA, F M. Horta solidária. Rio de Janeiro, 2008.

IBGE, Diretoria de Pesquisas, Coordenação de Trabalho e Rendimento, Pesquisa de Orçamentos Familiares (POF), 2008-2009.

SIDRA, 2011. 


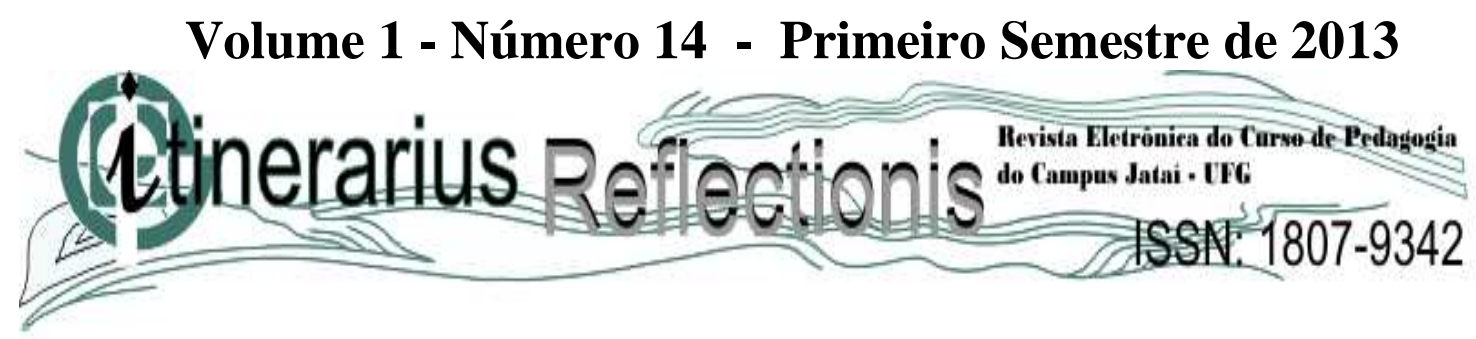

JESUS et al. A horta escolar como tema-gerador de uma escola rural no agreste sergipano: subsídios para o ensino de ciências. G. Ciências Humanas- 7 edição- 12. ensino de ciências (2011). Anais. 63 Reunião Anual da SBPC.

LOURO, D.T.F; SALOMÃO, S. R; PEREIRA, L. P. Brincar e aprender com a horta da creche: reflexões sobre o ensino de ciências na educação infantil. G. Ciências Humanas- 7 edição- 12. ensino de ciências (2011). Anais. 63 Reunião Anual da SBPC.

MAGALHÃES, A. M. A horta como estratégia de educação alimentar em creche. 2003. 120 p. Dissertação (Mestrado em Agroecossistemas) - Centro de Ciências Agrárias, Universidade Federal de Santa Catarina, Florianópolis.

MINISTÉRIO DA SAÚDE. Secretaria de Atenção à Saúde. Departamento de Atenção Básica. POLÍTICA NACIONAL DE ALIMENTAÇÃO E NUTRIÇÃO. 2.a edição revista

5. reimpressão Série B. Textos Básicos de Saúde Brasília - DF 2008.

MORGADO, F. S. A horta escolar na educação ambiental e alimentar: experiência

do Projeto Horta Viva nas escolas municipais de Florianópolis. 50 f. (Relatório de Graduação) - Curso de Agronomia da Universidade Federal de Santa Catarina, 2006.

OLIVEIRA, I. B. (Org.). Alternativas emancipatórias em currículo. São Paulo: Cortez Editora, 2004. Série Cultura, Memória e Currículo; vol. 4. In.: CRIBB; S. L. S. P. Contribuições da Educação Ambiental e Horta Escolar na Promoção de Melhorias ao Ensino, à Saúde e ao Ambiente [Editorial]. REMPEC - Ensino, Saúde e Ambiente, v.3 n 1 p. 42-60, Abril 2010.

PEREIRA E. N. et al; Construindo saberes através da implantação de horta escolar em uma escola pública da cidade do Jaboatão dos Guararapes, Pernambuco. 2008.

SEGURA, D.S.B. 2001. Educação ambiental na escola publica: da curiosidade ingênua à consciência critica. Editora: Annablime: Fapesp.

SOLEIL. Você sabe se alimentar? Dr. Soleil. Tradução de Tomoyoshi et al. $7^{\text {a }}$. ed. São Paulo: Paulus, 1992.

TURANO, W. A didática na educação nutricional. In: GOUVEIA, E. Nutrição Saúde e Comunidade. São Paulo: Revinter, 1990. 246 p. 